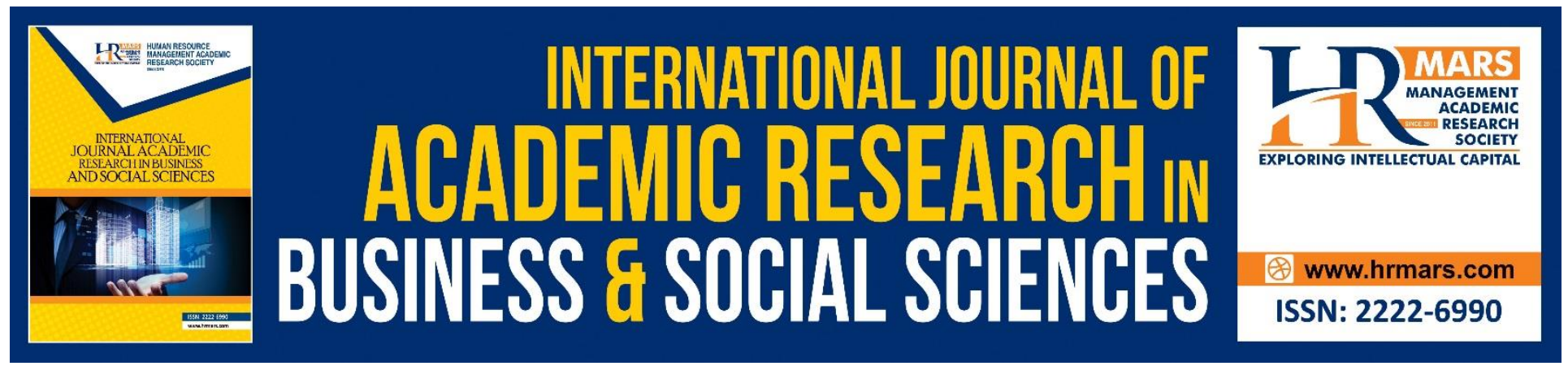

\title{
Analysis of the Legislative Resolution of the European parliament on the Common European Sales Law
}

Jasmina Mlađenović

To Link this Article: http://dx.doi.org/10.6007/IJARBSS/v9-i1/5519

DOI: $\quad 10.6007 /$ IJARBSS/v9-i1/5519

Received: 15 Dec 2018, Revised: 24 Jan 2019, Accepted: 29 Jan 2019

Published Online: 07 Feb 2019

In-Text Citation: (Jasmina, 2019)

To Cite this Article: Jasmina. (2019). Analysis of the Legislative Resolution of the European parliament on the Common European Sales Law. Mlađenović, 9(1), 1155-1165.

Copyright: (c) 2019 The Author(s)

Published by Human Resource Management Academic Research Society (www.hrmars.com)

This article is published under the Creative Commons Attribution (CC BY 4.0) license. Anyone may reproduce, distribute, translate and create derivative works of this article (for both commercial and non-commercial purposes), subject to full attribution to the original publication and authors. The full terms of this license may be seen

at: http://creativecommons.org/licences/by/4.0/legalcode

Vol. 9, No. 1, 2019, Pg. 1155 - 1165

http://hrmars.com/index.php/pages/detail/IJARBSS

JOURNAL HOMEPAGE

Full Terms \& Conditions of access and use can be found at http://hrmars.com/index.php/pages/detail/publication-ethics 


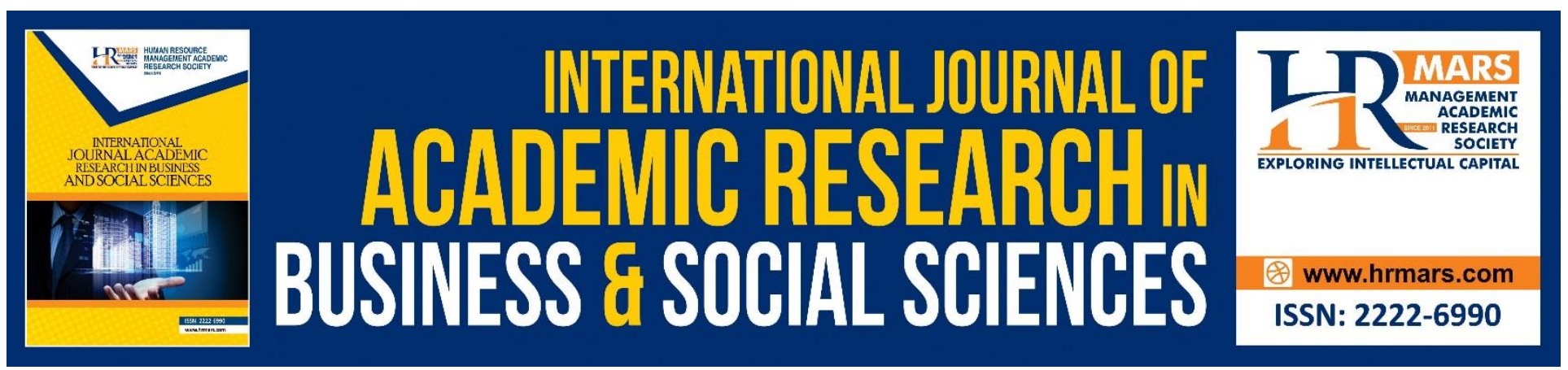

\title{
Analysis of the Legislative Resolution of the European parliament on the Common European Sales Law
}

\author{
Jasmina Mlađenović \\ Polytehnic in Pozega, Vukovarska 17, Pozega, Republic of Croatia \\ Email: jmladenovic@vup.hr, jasminamladjenovic@gmail.com
}

\begin{abstract}
The aim and objective of this paper is to analyse the development of the contract law of the European Union and review the main changes introduced by the European Parliament Legislative Resolution on the Common European Sales Law compared to the original Proposal for a Regulation from 2011. At the beginning of the paper, an overview of the development of the European Union's contract law over the last decades has been presented. It includes various Directives and the Principles of European contract law by the Commission on European Contract Law. The paper further continues with explaining the ordinary legislative procedure in the European parliament and showing the process of adopting the Legislative Resolution on the Common European Sales Law to the adoption in the Council. The legal basis for its adoption is analysed in sequence. Furthermore, the structure and content of the Proposal and the Legislative Resolution is outlined. Finally, the new provisions of the Common European Sales Law that have been adopted by the European Parliament are explained. Keywords: Contract Law, Sales, Cesl, European Parliament, Legislative Procedure
\end{abstract}

\section{Introduction}

In recent decades, the European Union is trying to harmonize contract law of Member States to facilitate the functioning of the internal market. Companies wishing to do business in other Member States must adapt their business to the legal regulations of the Member States with whose citizens and businesses they want to operate because they have to provide the highest level of protection to their customers which is a particular problem for small and medium-sized enterprises that have to invest significant resources in order to succeed in that.

One of the ideas of promoting cross-border sales was the creation of a Common European Sales Law. The proposal to regulate this matter was introduced in 2011 and after consideration by the relevant committees, the Legislative Resolution was adopted in the European Parliament in 2014 with numerous amendments, which will be further discussed below.

This paper aims to show the direction in which the European contract law is going. The objective is to review the main changes introduced by the European Parliament Legislative Resolution on the 
Common European Sales Law compared to the original Proposal for a Regulation from 2011, after consultations with the relevant committees, national parliaments and other key stakeholders.

A number of scientific methods have been used for making this paper. First, secondary data were explored using scientific literature on contract and international law. In addition, a deductive method was used as well as an inductive method that lead to general conclusions. The abstraction method divided the relevant from the irrelevant and during utilization of the method of classification the methods of specialization and generalization were used. In addition, the method of systems analysis and synthesis as well as the dialectic approach were also used.

\section{Development of the European contract law}

During the 1980s and 1990s European legislation sought to harmonize contract law of Member States, in particular in the part relating to consumer contracts by the adoption of various directives e.g. Directive 85/577/EEC relating to protection against the conclusion of contracts negotiated outside the place of business, Directive 93/13/EEC relating to unfair terms in consumer contracts, Directive 99/44/EC which covers certain aspects of the sale of consumer goods and associated guarantees. However, such directives required changes in the laws of Member States for domestic transactions also (Whittaker 2012). In resolutions A2-157/89 and OJ C 205/518, the European Parliament emphasized the importance of creating a European civil code for the establishment of a single internal market (Mišćenić 2012). Commission of then European Economic Community supported the drafting of the Principles of European contract law by the Commission on European Contract Law (the so-called Lando Commission). In 1995, the first composition of the Commission ended with the first phase of the work and published the first part of the Principles of European contract law which contained general provisions, performance, non-performance (breach of contract) and sanctions. In September 1992 the so-called Second Commission on European Contract Law started working and in 1999 published the second edition or the second part of the Principles. The second part contains rules on the formation, validity, interpretation and contents of the contract, the rules of representation, and also contains a revised version of the provisions of the first part. In 1997 the so-called Third Commission on European Contract Law started working. In March 2003, a third part of the Principles was published, which contains the rules on plurality of parties, the assignment, the substitution of the debtor, the transfer of the contract, the set-off, the statute of limitation, the nullity of the contract, the terms and the capitalization of interest. Final text of the Principles of European contract law consist of 17 chapters (general provisions, formation, authority of agents, validity, interpretation, contents and effects, performance, non-performance and remedies in general, particular remedies for non-performance, plurality of parties, assignment of claims, substitution of new debtor, set-off, prescription, illegality, conditions, capitalization of interest) (Petrić 2008).

In 2000s three principal ideas were developed in which direction the European Union should engage in the area of contract law. First, the existing contractual acquis seemed technically inconsistent, which could be improved by using a "legislator's tool-box" of "principles, model rules and definitions". Secondly, the technique of "minimum harmonization" failed to provide economic benefits of increased cross-border sales. This problem was to be solved so that EU legislation sets a minimum and maximum for consumer protection in Member States so that businesses do not need 
to spend money to find out about enhanced consumer protection in the Member States they want to deal with. Thirdly, the idea of an optional instrument of European contract law that the parties might choose to govern their contract has developed (Whittaker 2012). In 2003, the European Commission issued an announcement proposing the development of a Common Frame of Reference, which should include common provisions and terminology of European contract law and regulate specific contracts in consumer rights (Mišćenić 2012). In 2007 the European Union adopted a Regulation on the law applicable to non-contractual obligations (the so-called Rome II) and in 2008 the Regulation on the law applicable to contractual obligations (the so-called Rome I).

In April 2010 the European Commission established an expert group with the task of preparing the Common Frame of Reference of European Contract Law. Soon they published a feasibility study that was a set of rules on general contract law. Based on this, the draft Regulation was published in October 2011 (Kiraly 2015).

\section{Procedure for adoption of the Legislative Resolution}

The ordinary legislative procedure consists in the joint adoption by the European Parliament (EP) and the Council of a Regulation, Directive or Decision. They are considered to be co-legislators and interlocutors during the negotiations. The Commission has the role of reconciling the positions of the European Parliament and the Council, but also the power to alter or withdraw its proposal. In case of withdrawal it is necessary to state the reasons and the evidence for this.

Following the issue of the Commission's proposal, either co-legislator can propose to the other that they should begin negotiations with a view to reaching a first-reading agreement (Guide to the ordinary legislative procedure 2016).

On October $11^{\text {th }}$ 2011, the European Commission published a Proposal for a Regulation of the European Parliament and of the Council on a Common European Sales Law (CESL) and in accordance with art 294 (2) of the Treaty on the Functioning of the European Union submitted it to the European Parliament (Official Journal of the European Union No 2012/C 326/01).

As provided by the Rules of Procedure of the European Parliament (2018) after receiving the Commission's proposal, the President of the EP refers it to the relevant parliamentary committee for examination of its substance and, if appropriate, to other committees that may give their opinion on the matter (Rule 53). After deciding on the procedure to be followed for the examination of the proposal, the committee appoints a Rapporteur on the Commission proposal from among its members or permanent substitutes (Rule 49). The opening of negotiations for an individual legislative procedure needs to be authorised by a majority of members of the committee responsible. The Rapporteur is responsible for presenting a draft report to the parliamentary committee. In this draft, the Rapporteur summarises the Commission proposal and the views of the different parties involved. During the debate within the parliamentary committee, the Commission may defend its proposal and answer questions from members of the committee. The parliamentary committee first examines the legal basis for the proposal (Rule 39). During the examination of a proposal, the relevant parliamentary committee asks the Commission and the Council to keep it informed of the progress of that proposal in the Council and its working parties (Rule 43(2)). The plenary discusses the legislative proposal on the basis of the report drawn up by the relevant committee (Rule 59(1)), which will include any proposed amendments to the proposal, a draft legislative resolution, and if 
appropriate, an explanatory statement. In the draft resolution, the committee proposes that the plenary should either approve or reject the Commission proposal, or adopt amendments to it (Rule 59(2)). After the report has been adopted by the committee, it is still possible for an MEP or a group of MEPs, or for the Rapporteur, often acting on behalf of a political group, to table amendments during the plenary debates. (Guide to the Ordinary Legislative Procedure 2016)

The Committee on Legal Affairs of the European Parliament gave its opinion on the Proposal for the Regulation in September 2013, following the opinion of the Committee on the Internal Market and Consumer Protection from July 2013, the Committee on Economic and Monetary Affairs from October 2012 and the European Economic and Social Committee from March 2012. The Legal Affairs Committee supported the Proposal, in particular its optional character and legal form, but the Committee on Internal Market and Consumer Protection has proposed changing the form into a directive which would harmonise certain aspects of the seller's liability towards consumers and supplement the existing Consumer Rights Directive. The latter also had doubts on the suitability of the Commission's proposal and warned that it would complicate the legal situation and would not be disadvantageous to consumers. The Committee on Economic and Monetary Affairs took a more favourable view of the Proposal and supported it (Manko 2018).

After a debate in the Council of the European Union and the European Parliament on 26 February 2014, in first reading, following the ordinary legislative procedure, by a simple majority, the Commission's proposal was adopted with 266 amendments.

The text of the Legislative Resolution on a Common European Sales Law has been published in the Official Journal of the European Union on August $29^{\text {th }} 2017$ (C 285/64).

In the event that the Council, by a qualified majority (or unanimously in cases where the Commission disagrees with its amendments), approves the EP's position in the first reading, the Common European Sales Law will be adopted. In case the Council does not approve the EP position in its first reading, it makes its own position in the first reading. When the Council's position is received and published at the plenary session of the EP, a period of three months for the second reading begins.

\section{Legal basis for the adoption of CESL}

As stated in the Proposal for a Regulation, the Common European Sales Law is a set of legal rules regulating the sale of goods, digital content and related services such as installation, maintenance, repair etc. between a business and a consumer and between two businesses provided that at least one party is from a member state of the European Union and a small or a medium-sized enterprise. Such a set of rules should exist as a second regime within the legal system of each EU country.

The Proposal for a Regulation is based on Article 114 of the Treaty on the Functioning of the European Union (Official Journal of the European Union No 2012/C 326/01), which states that "The European Parliament and the Council shall, acting in accordance with the ordinary legislative procedure and after consulting the Economic and Social Committee, adopt the measures for the approximation of the provisions laid down by law, regulation or administrative action in Member States which have as their object the establishment and functioning of the internal market...The Commission, in its proposals envisaged in paragraph 1 concerning health, safety, environmental protection and consumer protection, will take as a base a high level of protection, taking account in particular of any 
new development based on scientific facts. Within their respective powers, the European Parliament and the Council will also seek to achieve this objective."

Although some authors find that the article in question is not a valid legal basis for the adoption of such a set of rules since it would exist together with national law, so it would not harmonize or replace them. Thus Božić (2012) considers that the appropriate legal basis would be art 352 which reads:

"1. If action by the Union should prove necessary, within the framework of the policies defined in the Treaties, to attain one of the objectives set out in the Treaties, and the Treaties have not provided the necessary powers, the Council, acting unanimously on a proposal from the Commission and after obtaining the consent of the European Parliament, shall adopt the appropriate measures. Where

the measures in question are adopted by the Council in accordance with a special legislative procedure, it shall also act unanimously on a proposal from the Commission and after obtaining the consent of the European Parliament.

2. Using the procedure for monitoring the subsidiarity principle referred to in Article 5(3) of the Treaty on European Union, the Commission shall draw national Parliaments' attention to proposals based on this Article.

3. Measures based on this Article shall not entail harmonisation of Member States' laws or regulations in cases where the Treaties exclude such harmonisation.

4. This Article cannot serve as a basis for attaining objectives pertaining to the common foreign and security policy and any acts adopted pursuant to this Article shall respect the limits set out in Article 40, second paragraph, of the Treaty on European Union. "

Mišćenić (2012) also considers this provision to be the most appropriate legal basis for the purpose set out in the Treaty on the Functioning of the European Union, namely the establishment or functioning of the internal market.

Kiraly (2015) argues that this sensitive legal base issue is the reason why the Proposal is presented as the second contractual right regime within the legal system of the member states instead of the 28th European legal system because CESL harmonises national law. Although he states that art 114 does not cover optional instruments and that art 325 was a better basis for the adoption of such instruments but the price of unanimous decision in the Council is great.

\section{Structure of the Proposal vs. structure of the Legislative Resolution}

The 2011 Proposal for a Regulation consisted of three parts:

1. The Regulation specifying the objective and subject matter, defining the terms used in the Regulation, explaining the optional nature of CESL, determining the territorial scope, the type of contract to which the contract may be applied, the parties to the contract, explaining that the choice for CESL requires an agreement of the parties to that effect, requiring Member States to ensure that there are sanctions in place for breaches by the traders of the duty to comply with the special requirements, explaining the consequences of choosing CESL, the options available to member states, requiring Member States to notify final judgments of their courts which give an interpretation of the provisions of the CESL or any other provision of the Regulation in order that the information about it would be available to public, obligation to revise CESL application and explaining entering into force, 
2. Annex I to the Regulation containing the contract law rules, respectively the text of the CESL with introductory provisions, the provisions on pre-contractual information and rules $s$ that parties should have prior to the conclusion of the contract, provisions for how contract terms need to be interpreted in case of doubt, the rights and obligations of the parties, as well as remedies, damages, interest, restitution and prescription.

3. Annex II containing the model information notice provided by the trader to the consumer before agreeing to use CESL.

The structure of the Legislative Resolution differs from the structure of the Proposal for a Regulation in a way that the text of the Regulation and the text of Annex I are merged as it has been found that such separation is unnecessary and confusing.

Legislative Resolution consists of four parts:

1. The Regulation that has a total of four titles, eight parts, eighteen chapters, and 186 articles. Title I contains part on the application of the instrument. Title II contains the provisions of the Common European Sales Law that include the introductory provisions, the general principles and their application, the provisions on making a binding contract, the pre-contractual information, the conclusion of the contract, the right to withdraw and the defects in consent. The part relating to the assessment of what is in the contract contains provisions on interpretation, contents and effects and unfair contract terms. The part entitled Obligations and remedies of the parties to a sales contract or a contract for the supply of digital content contains general provisions, then the seller's obligations, the buyer's remedies, the buyer's obligations, the seller's remedies and the passing of risk clauses. Next is a part on obligations and remedies of the parties to a related service contract, part on damages and interest, part on the restitution and part on prescription. Title III deals with flanking measures, and title IV contains final provisions,

2. Appendix 1 that contains model instructions on withdrawal,

3. Appendix 2 that contains a model withdrawal form,

4. Annex that contains standard information notice.

\section{Overview of the main characteristics of the Legislative Resolution}

Contrary to the Proposal for a Regulation, the European Parliament's Resolution limits itself to distance contracts, in particular online contracts, as an integral part of the legal order in the territory of the Member States, "in so far as its scope allows and where parties have validly agreed to use it, the Common European Sales Law should apply instead of the first national contract-law regime within that legal order". The Resolution further clarifies that choosing CESL is not a choice between two national legal orders but two different regimes within the same national legal order.

In the opening statement it also points out that the Regulation needs to be more precise to define who should be considered a consumer and stresses that for all matters falling within the scope of the Common European Sales Law, this law applies once there is a valid agreement on its use.

The novelty introduced by the Resolution is that: "The Common European Sales Law provides a coherent set of rules adapted to the distance supply, and in particular the supply online, of digital content and related services. It should be possible for those rules to also apply when digital content or related services are provided using a cloud, in particular when digital content can be downloaded from the seller's cloud or temporarily stored in the provider's cloud". 
As it involves digital content offered in combination with separate paid goods or services that include non-monetary consideration, in these cases it determines that the remedy of the buyer should be limited to damages. "On the other hand, the buyer should be able to have recourse to the full range of remedies, except price reduction, even if he is not obliged to pay a price for the supply of digital content, provided that his counter-performance, such as the provision of personal data or other utility having commercial value for the supplier, equals the payment of the price, given that in such cases the digital content is not actually supplied free of charge."

It further prescribes that CESL may also be used for linked contracts between the same parties, although it is not a sales contract, a contract for the supply of digital content or related services, but is subject to the applicable national law. It may also be used for contracts involving any element other than the sale of goods, the supply of digital content, or the provision of related contracts if these elements are divisible and their price can be apportioned.

In the event that the agreement of the parties to the use of the CESL is invalid, the respective national law applicable in accordance with the relevant rules of international private law shall be applied.

The provisions on unfair commercial practices (referred to in Directive 2005/29/EC of the European Parliament and of the Council) state that CESL should cover them in so far as they overlap with the rules of contract law and in particular those that may lead to avoidance of the contract due to threats, frauds, mistakes or unfair exploitation.

The Resolution supports the creation of a database that would comprise the final relevant court decisions regarding CESL but adds that it should be easily accessible, fully systematized and easily searchable. The judgments should be communicated on the basis of a standard judgment summary which should be succinct and easily accessible and consist of five sections which should include main elements of the judgment, namely: the issue and the relevant article of the Common European Sales Law, a brief summary of the facts, a short summary of the main arguments, the decision and the reasons for the decision, which clearly state the principle decided.

The European Parliament's Resolution proposes to the Commission to provide a commentary on the Common European Sales Law, which would provide a clear and comprehensive exegesis of the articles. It also proposes to consumers and traders who conclude a contract based on CESL to consider alternative dispute resolution. It holds that "the Commission should work towards the development of European model contract terms with the assistance of a working group, composed mainly of groups representing consumers and businesses and supported by academics and practitioners. Such model contract terms could usefully complement the Common Sales Law rules when describing the specific features of a given contract, and should take into account the particularities of relevant commercial sectors. They should respond to stakeholders' needs and draw lessons from the initial practical experience of the use of the Common European Sales Law. The model contract terms should be made available to the public as they would provide added value to traders who choose to conclude cross-border contracts using the Common European Sales Law".

It adds that particular attention should be paid to the question whether the limitation to distance contracts, and in particular online contracts is still appropriate or could be more widespread, including the on-premises contracts.

The text of the Regulation has been adjusted in accordance with the introductory explanations. In the first article already is emphasized that CESL specifically refers to small or medium-sized 
enterprises. The definitions of a trader and a consumer have been extended and definitions of creditors and debtors are added. The terms of good faith and fair dealing, standard contract terms and loss have been redefined and the definition of the mandatory rule has been added. The entire glossary has been rearranged so that it groups definitions by these categories: persons involved, general contract law terms, types of contracts, terms relating to specific types of contract.

The novelty of the Resolution, given that it is limited to distance contracts, is that it can be used in the case of a contract between traders, without the condition that at least one of these contracting parties is a small or medium-sized enterprise as originally proposed. Also, the resolution allows traders to choose the partial application of CESL in mutual relations but they may not exclude mandatory provisions.

One of the amendments clarifying the relationship between CESL and Rome I Regulation is the one that says that all the matters covered by the Common European Sales law are govern by that law and not the contract-law regime that would govern the contract within the legal order determined as the applicable law.

Unlike the Proposal, the Resolution regulates the negotiations with reference to CESL even in case the contract is not concluded.

The Resolution in art 11 . clearly defines the matters that are covered by CESL and those that are not. The proposers of the amendments considered that it was necessary to further define what an offer should contain so as sufficient content states an object, a quantity or duration, and a price. It was also important to emphasize that "in relations between a trader and a consumer, a reply by the offeree which states or implies additional or different contract terms shall in any event constitute a rejection and a new offer".

The provisions on mistakes, fraud, threats and unfair exploitation by third parties were also added. In situations where the consumer should be aware of contract terms that have not been individually negotiated, it is emphasized that the warning is sufficient if the conditions are:

"(a) presented in a way which is suitable to attract the attention of a consumer to their existence; and

(b) given or made available to a consumer by a trader in a manner which provides the consumer with an opportunity to comprehend them before the contract is concluded".

The Resolution has shortened the long period of prescription from 10 to 6 years and the expressions in the text of the Regulation are in line with the expressions in the text of the Directive on consumer rights (Official Journal of the European Union, No 2011/L 304).

\section{Conclusion}

The Proposal for a Regulation on the Common European Sales Law aimed at improving the establishment and functioning of the internal market by facilitating the expansion of cross-border sales and purchases in a manner that would allow a uniform set of contract law rules. Although very ambitious and comprehensive project, it has been completed in a relatively short time frame and as such, it has encountered a large number of criticisms, both from the legal profession and from many EU member states. In the meantime, numerous discussions on the above mentioned proposal were conducted and opinions of the relevant committees were received. In the debate before the European Parliament a legislative resolution with numerous amendments was adopted at the 
Commission's proposal. The changes primarily highlighted the focus on small and medium-sized enterprises and distance contracts, established their place in the legal regimes of member states as a second contract law regime and expanded the effects to negotiations before concluding the contract. The content of an offer is defined more precisely, digital content that is not paid with money is covered and its application is extended to related contracts.

Despite numerous adjustments of the text of the Regulation, the Council did not discuss it and the European Parliament did not appoint a rapporteur, although the proposal was never officially withdrawn. The Commission has put CESL in its 2015 work program on a list of proposals that need to be modified and in 2015 presented a modified proposal for the implementation of the Digital Single Market that separates contracts for the supply of digital content and those for the online and other distance sales of goods. In 2017 the Commission submitted an amended proposal covering all types of sales of goods without limitation for the online and other distance sales of goods. Taught by experience during the negotiations on CESL it contains a set of unique consumer rights for all consumers in the European Union that are uniquely interpreted and implemented in all Member States and should replace the Directive on certain aspects of the sale of consumer goods and associated guarantees from 1999.

The Common European Sales Law, according to current trends, will probably never be adopted by the Council of the European Union, but the efforts of the Commission to establish a single internal market continue.

This paper is a contribution to the existing theories in the area of European sales law and will be of use to everyone involved in theory or practice regarding issues related to sales of goods. Its practical contribution to this context is reflected in the fact that a comprehensive review of the latest steps in forming a single internal market was given and is a certain basis for further scientific research or for practical application.

\section{References}

1. Božić, M. (2012, October). Common European (cross-border) Sales Law-the political background and legal basis of the regulation COM (2011) 635. Croatian Law review, 12 (10), $14-23$.

2. Consolidated version of the Treaty on the functioning of the European Union. Official Journal of the European Union, No 2012/C 326/01.

3. European Parliament legislative resolution on the proposal for a regulation of the European Parliament and of the Council on a Common European Sales Law. Official Journal of the European Union, No 2017/C 285/64.

4. Guide to the Ordinary Legislative Procedure (2016, March) Luxembourg: Publications Office of the European Union. Retrieved from:

https://www.consilium.europa.eu/media/29872/qc0415816enn.pdf 
5. Kiraly, M. (2016, October). The Rise and Fall of Common European Sales Law. ELTE Law Journal, 2015/2, 31-42.

6. Manko, R. (2018). Common European Sales Law (CESL). Legislative train schedule, connected digital single market. Retrieved from: http://www.europarl.europa.eu/legislativetrain/theme-connected-digital-single-market/file-common-european-sales-law

7. Mišćenić, E. (2012, October). European contract law on the way from soft to hard law: an overview of the optional Common European Sales Law (CESL). Collected papers of the Law Faculty of the University of Rijeka, 33 (2), 695-745.

8. Petrić, S. (2008, February). Introduction to the Principles of European Contract Law (Lando principles). Collected papers of the Law Faculty of the University of Rijeka, 29 (1), 335-370.

9. Rules of Procedure of the European Parliament (2018, July). Retrieved from: http://www.europarl.europa.eu/sides/getDoc.do?pubRef=-//EP//NONSGML+RULES$E P+20180731+0+D O C+P D F+V 0 / / E N \& l a n g u a g e=E N$

10. Whittaker, S. (2012, July). The Proposed „Common European Sales Law“: Legal Framework and the Agreement of the Parties. The Modern Law review, 75(4), 578-605. 